\title{
II CONFERÊNCIA NACIONAL DE POLÍTICAS PARA AS MULHERES: IMPLICAÇÕES PARA A ENFERMAGEM BRASILEIRA
}

\author{
Second national conference on policies for women: \\ Implications for brazilian nursing \\ II conferencia nacional de políticas para mujeres: \\ Consecuencias para la enfermería brasileña
}

Maria Celeste Landerdahl ${ }^{1}$

Transformações significativas nas esferas econômica, social e cultural no Brasil têm repercutido de forma relevante na área de políticas públicas. Em relação à saúde em especial, percebe-se um movimento crescente a partir da década de 70 do século XX, na busca por um modelo assistencial condizente às necessidades dos brasileiros.

Nesta caminhada, o Sistema Único de Saúde (SUS) vem sendo construído por meio de uma política fundada em pilares que elegem a promoção da saúde como estratégia para defender a vida. Tal sistema assegura a saúde como resultante das condições de vida das pessoas, configurando-se como um direito de cidadania ${ }^{1}$, dimensão em que o respeito aos direitos humanos deve vigorar como princípio básico, possibilitando uma visão ampliada de saúde a qual deve ser consolidada no contexto em que os sujeitos vivem, trabalham e se relacionam.

A efetivação, no entanto, de uma lógica assistencial que esteja em consonância com as reais demandas da vida dos indivíduos, evoca a necessidade de participação dos sujeitos na elaboração, acompanhamento e avaliação de políticas públicas².

Nessa esteira, percebe-se que as mulheres, das mais diversas classes sociais, cultura e raça, seja por meio de movimentos femininos/feministas ou em seu próprio espaço doméstico e de trabalho, têm se mobilizado na conquista por seus direitos. Tal realidade ficou evidente na II Conferência Nacional de Políticas para as Mulheres (CNPM), a qual aconteceu no Centro de Convenções de Brasília, de 17 a 20 de agosto de 2007, com a participação de mais de 2.500 mulheres, eleitas em 600 Conferências Municipais, Regionais e Estaduais. Essas mulheres, das quais faziam parte indígenas, negras, brancas, lésbicas, ciganas, travestis, detentas, jovens, idosas, caboclas, deficientes, ribeirinhas, trabalhadoras urbanas e rurais, domésticas, donas-de-casa, sindicalistas e militantes de movimentos sociais do campo e da cidade, vieram de todos os cantos do país. Ficaram acomodadas em 1.101 quartos de 11 hotéis na capital federal, de onde eram transportadas em 30 ônibus até o Centro de Convenções, e participaram de 20 grupos de trabalho cujo objetivo era avaliar o I Plano Nacional de Políticas para Mulheres, o qual está vigorando desde 2005; bem como apontar novos eixos para o período 2008-20113.

Dentre os eixos avaliados constavam: 1 - autonomia, igualdade no mundo do trabalho e cidadania; 2 - educação inclusiva e não-sexista; 3 - saúde das mulheres, direitos sexuais e direitos reprodutivos, autonomia das mulheres sobre seu corpo com respeito às suas diversidades e especificidades; 4 - enfrentamento a todas as formas de violência contra as mulheres; 5 - gestão, monitoramento, avaliação e controle social do Plano Nacional de Políticas para as Mulheres ${ }^{3}$.

Os novos eixos apontados na II CNPM a partir das discussões inserem: 1 - participação política das mulheres e igualdade em todos os espaços de poder; 2 - desenvolvimento sustentável no meio rural, na cidade, na floresta, com garantia de justiça ambiental, inclusão social, soberania e segurança alimentar; 3 - direitos das mulheres a terra e moradia digna, bem como serviços, garantindo a qualidade de vida nas áreas urbanas e rurais, considerando as etnias e comunidades tradicionais; 4 - cultura, comunicação e mídia igualitária, democrática e não-discriminatória; 5 enfrentamento do racismo, sexismo e lesbofobia; 6 - enfrentamento das desigualdades que atingem as mulheres jovens e idosas em suas especificidades e diversidades ${ }^{3}$.

$\mathrm{Na}$ condição de uma das delegadas pelo Rio Grande do Sul, posso afirmar que as discussões permitiram visualizar algumas conquistas, porém, ficou evidente que há muito a se fazer na busca pela igualdade de direitos e oportunidades entre mulheres e homens, como condição indispensável para a justiça, a paz e o progresso no mundo. Para tanto, é preciso 
conhecer as diretrizes de políticas propostas para as brasileiras, se engajar na luta e exercer o controle social necessário para sua implementação. Essa tarefa é também nossa, dos profissionais da enfermagem brasileira, uma vez que trabalhamos com a saúde dos indivíduos, esfera em que as mulheres estão expostas a padrões distintos de sofrimento, adoecimento e morte, tendo em vista a organização social das relações de gênero ${ }^{4}$, realidade que justifica políticas diferenciadas.

Palavras-chave: Políticas Públicas. Direitos da Mulher. Saúde da Mulher

\section{Referências}

1. Lei n 8080 , de 19 setembro de 1990. Dispõe sobre as condições de promoção, proteção e recuperação da saúde, a organização e o funcionamento dos serviços correspondentes, e dá outras providências. Diário Oficial da República Federativa do Brasil, Brasília (DF), 20 set 1990.

2. Lei n 8142 , de 28 de dezembro de 1990. Dispõe sobre a participação da comunidade na gestão do Sistema Único de Saúde (SUS) e sobre as transferências intergovernamentais de recursos financeiros na área da saúde e dá outras providências. Diário Oficial da República Federativa do Brasil, Brasília (DF), 31 dez 1990.

3. Conselho Nacional dos Direitos da Mulher (BR). Secretaria Especial de Políticas para as Mulheres. $2^{\text {a }}$ Conferência Nacional de Políticas para as Mulheres. Brasília (DF); 2007.

4. Ministério da Saúde (BR). Política Nacional de Atenção Integral à Saúde da Mulher: princípios e diretrizes. Brasília (DF); 2007.

\section{Brief Communication}

Maria Celeste Landerdahl

Significant changes in economic, social and cultural spheres in Brazil have been relevant in the area of public policies especially concerning health, where it is possible to notice a growing movement since 1970 searching a model that fits the Brazilian necessities.

In this way, the National Health System (SUS) is being built based on a policy that elects health promotion as a strategy to defend life. This system ensures health as a result of the conditions of life, placing it as a citizenship ${ }^{1}$ right, dimension where the respect for the human rights must be a basic principle allowing a wide vision about health which must be consolidated in the context where people live and work.

The execution of a logical care that is in agreement with the real demands of human life implies on the necessity of participation in the preparation, monitoring and evaluation of public ${ }^{2}$ policies.

It is noticed that women from many different social, cultural and racial lawyers, also from women/feminist movements or in their own houses and workplaces, have been mobilized to fight for their rights. This reality was evident in the Second National Conference on Policies for Women (CNPM), which happened at the Conventions Center of Brasilia, from August 17 to August 20, 2007 with the participation of more than 2500 elected women in 600 Municipal, Regional and State Conferences. Th e s e women -indigenous, black, white, gay, transvestites, young, old, deficient, urban and rural workers, housekeepers, trade unionists and militants of social life and city movements - came from every part of the country. They were in 1.101 rooms in 11 hotels of the Federal Capital, they were daily transported to the Conventions Center in 30 buses and attended 20 working groups whose purpose was to evaluate the First National Plan concerning Policies for Women, which is effective since 2005; as well as to point new priorities for the 2008-20113 period.

The evaluated themes were: 1 - autonomy, equality at work and citizenship; 2 - inclusive and non-sexist education; 3 women health, sexual and reproductive rights, women autonomy over their body respecting the diversity and specificities; 4 - to fight against all kinds of violence against women; 5 - management, monitoring, evaluation and social control concerning the National Plan of Policies for Women ${ }^{3}$ among others .

The new targets mentioned during the discussions in the II CNPM were: 1 - the participation of women in politics and equality in every area, including the power ones; 2 - sustainable development in rural areas, in the city and in the forest with the guarantee of environmental justice, social inclusion, sovereignty and food security; 3 - women rights to land, decent housing and services ensuring quality of life in urban and rural areas considering ethnical and traditional communities; 4 - equal, democratic and nondiscriminatory culture, communication and media; 5 - to fight against racism, sexism and homophobia; 6 - fight against inequalities that affect young and old women in their specificities and diversities ${ }^{3}$.

As one of the Rio Grande do Sul representatives, I can say that the discussions allowed to see some achievements, however, it is evident that there is much more to do to reach equal rights and opportunities among women and men and make this an indispensable condition for justice, peace and progress in the world. So, we must know the policy guidelines for Brazilian women to be able to engage in the fight and practice social control, necessary for its implementation. This work is also ours, professionals of Brazilian nursing, once we work with individual health, sphere where women are exposed to different patterns of suffering, illness and even death due to the social organization of gender ${ }^{4}$ relations reality which justifies differentiated policies.

Keywords: Public Policies. Woman's Rights. Woman's Health. 


\section{Comunicación Breve}

Maria Celeste Landerdahl

Transformaciones significativas en las esferas económica, social y cultural en Brasil han repercutido de manera relevante en el ámbito de las políticas públicas. En relación a la salud, en particular, nos encontramos con un movimiento creciente a partir de los años 70 del siglo XX, en la búsqueda de un modelo de atención en consonancia con las necesidades de los brasileños.

De esta manera, el Sistema Unificado de Salud (SUS) se está construyendo a través de una política basada en pilares que eligen la promoción de la salud como una estrategia para defender la vida. Este sistema garantiza la salud como consecuencia de las condiciones de vida de las personas, estableciendolo como un derecho de ciudadanía ${ }^{1}$, dimensión en que el respeto a los derechos humanos debe aplicarse como principio básico, lo que permite una visión más amplia de la salud que debe consolidarse en el contexto en que los sujetos viven, trabajan y se relacionan.

La ejecución, sin embargo, de una lógica de la atención que sea en consonancia con las exigencias reales de la vida humana evoca la necesidad de participación de los sujetos en la elaboración, seguimiento y evaluación de políticas públicas².

En este sentido, encontramos que las mujeres de diversas clases sociales, razas y culturas, sea a través de los movimientos femeninos/femenistas o en su proprio espacio de casa y de trabajo, se movilizan para la conquista de sus derechos. Esta realidad se volvió evidente en la ll Conferencia Nacional sobre Políticas para la Mujer (CNPM), que ocurrió en el Centro de Convenciones de Brasilia, del 17 al 20 de agosto de 2007, con la participación de más de 2.500 mujeres, elegidas en 600 Conferencias Municipales, Regionales y Estatales. Estas mujeres, indígenas, negras, blancas, homosexuales, gitanas, jóvenes, ancianas, discapacitadas, trabajadoras urbanas y rurales, amas da casa, sindicalistas y militantes de movimientos el ámbito social del campo y de la ciudad, vinieron de todos los rincones del país. Ellas se quedaron en 1.101 habitaciones en 11 hoteles de la capital federal, de donde fueron transportadas en 30 autobuses para el Centro de Convenciones y participaron de 20 grupos de trabajo cuyo objetivo fue evaluar el Primer Plan Nacional de Políticas para la Mujer, que es efectivo desde el año 2005; así como para identificar nuevas rutas para el período 2008-20113.

Entre los temas evaluados estaban: 1 - la autonomía, la igualdad en el trabajo y la ciudadanía; 2 - la educación inclusiva y no sexista, 3 - la salud de la mujer, los derechos sexuales y derechos reproductivos, la autonomía de la mujer sobre su cuerpo con respecto a su diversidad y especificidades; 4 - para hacer frente a todas las formas de violencia contra la mujer, 5 - gestión, seguimiento, evaluación y control social del Plan Nacional de Políticas para las Mujeres3.

Los nuevos objetivos identificados en el II CNPM después de los debates son: 1 - la participación política de la mujer y la igualdad en todas las esferas de poder, 2 - el desarrollo sostenible en las zonas rurales en la ciudad, en el bosque, con una garantía de la justicia ambiental, la inclusión social, la soberanía y la seguridad alimentaria; 3 - los derechos de la mujer a la tierra, la vivienda digna y servicios, garantizando la calidad de vida en las zonas urbanas y rurales, teniendo en cuenta la composición étnica y las comunidades tradicionales, 4 - la cultura, la comunicación y los medios de comunicación igualitarios, democráticos y no discriminatorios, 5 - combatir el racismo, el sexismo y la lesbofobia; 6 - combatir las desigualdades que afectan a las mujeres jóvenes y de edad avanzada en sus especificidades y diversidades ${ }^{3}$.

Como una de las delegadas por Rio Grande do Sul, puedo decir que los debates han permitido ver algunos logros, no obstante, quedó claro que hay mucho por hacer en la búsqueda de la igualdad de derechos y oportunidades entre mujeres y hombres, como condición previa para la justicia, la paz y el progreso en el mundo. Para ello, debemos conocer las directrices de política propuestas para las brasileñas, participar en la lucha y ejercer el control social necesario para su aplicación. Esta tarea es también nuestra, profesionales de la enfermería brasileña, ya que trabajamos con la salud de las personas, ámbito en que las mujeres están expuestas a distintos modelos de sufrimiento, enfermedad y muerte, con miras a la organización social de las relaciones de género ${ }^{4}$; realidad que justifica diferentes políticas.

Palabras clave: Políticas Públicas. Derechos de la Mujer. Salud de la Mujer. 